kuLTura - мeDia- теоLogia

ISSN 2081-8971

$2017 \mathrm{nr} 30$, s. $162-173$.

\title{
Powstanie Warszawskie
}

oczami Sióstr Zmartwychwstanek - obrona „Twierdzy Zmartwychwstanek”

\author{
The Warsaw Uprising eyed by Sister of Resurrection \\ - defence of the "Sisters of the Resurrection Fortress"
}

\begin{abstract}
STRESZCZENIE:
Powstanie WARSZaWSKIE JEST JEDNYM Z NAJBARDZIEJ DRAMATYCZNYCH WYDARZEN W WISTORII POLSKI. ZRYW ZBROJNY PRZECIWKO NIEMIECKIEMU OKUPANTOWI ZAKOŃCZYŁ SIĘ KLĘSKĄ. ODWAGA I MĘSTWO POLAKÓW, ZARÓWNO ŻOŁNIERZY, JAK I LUDNOŚCI CYWILNEJ, DO DZIŚ BUDZI PODZIW I ZDUMIENIE. WŚRÓD BOHATERÓW

TYCH TRAGICZNYCH DNI NIE ZABRAKŁO SIÓSTR ZAKONNYCH. SZCZEGÓLNE MIEJSCE NA KARTACH HISTORII POWSTAŃCZEJ WARSZAWY ZAJMUJĄ SIOSTRY ZMARTWYCHWSTANKI. ODDAJĄC SWÓJ DOM ZAKONNY NA SZPITAL POWSTAŃCZY NIE PRZYPUSZCZAEY NAWET, ŻE

NIEBAWEM STANIE SIĘ ON NIEUGIĘTYM PUNKTEM OBRONY MIASTA: „REDUTĄ ŻOLIBORZA”, „TWIERDZĄ

ZMARTWYCHWSTANEK”. ARTYKUŁ PRZEDSTAWIA RELACJE SIÓSTR Z OGARNIĘTEJ WALKĄ DZIELNICY

WARSZAWY, NA PODSTAWIE KTÓRYCH MOŻNA ODTWORZYĆ DRAMATYCZNĄ HISTORIĘ ŻOLIBORSKIEGO KLASZTORU, JAK I ZYSKAĆ WGLĄD W POSTAWĘ SIÓSTR W OBLICZU ZAGŁADY.
\end{abstract}

\section{SŁOWA KLUCZOWE:}

POWSTANIE WARSZAWSKIE, 1944 R., REDUTA ŻoliborZa, Twierdza ZMartwychWSTANEK, ZgromadZenie Sióstr ZMartwychwStania PAŃSKIEGO, ZMARTWYCHWSTANKI

\section{ABSTRACT:}

THE WARSAW UPRISING IS ONE OF THE MOST DRAMATIC EVENTS IN POLISH HISTORY. AN ACT OF OPPOSITION TO THE GERMAN OCCUPATION RESULTED IN A GREAT DISASTER. VALOUR AND COURAGE OF MANY POLES, BOTH SOLDIERS AND CIVILIANS, STILL AWAKEN AN ADMIRATION AND AMAZEMENT FOR THEM. INDEED, AMONG THE HEROES OF THOSE TRAGIC DAYS THERE WERE ALSO CATHOLIC NUNS. SISTERS OF THE RESURRECTION HAVE A SPECIAL PLACE IN THE HISTORY OF INSURGENT WARSAW. GIVING THEIR CONVENT FOR INSURGENT HOSPITAL THEY DID NOT SUPPOSE THAT SOON IT WILL BECOME A RELENTLESS POINT OF THE CITY DEFENCE: "STRONGHOLD OF ZOLIBORZ", “the Sisters of the Resurrection Fortress”. The ARTICLE PRESENTS A HISTORY OF THE MENTIONED EARLIER MONASTERY, THE SISTER'S MEMORIES OF CITY DISTRICT DURING THE BATTLE, BASED ON WHICH, WE CAN RECONSTRUCT DRAMATIC STORY OF THEIR NUNNERY AS WELL TO GAIN AN INSIGHT INTO THE NUN'S ATTITUDE IN THE FACE OF HOLOCAUST.

\section{KEYWORDS:}

WARSAW UpRISING, 1944, Fortress Sisters OF the Resurrection, The Congregation of the Sisters of THE RESURRECTION 
$\mathrm{P}$ rzy ulicy Krasińskiego 31 na warszawskim Żoliborzu znajdują się klasztor Sióstr Zmartwychwstanek ${ }^{1}$ oraz prowadzona przez Zgromadzenie placówka edukacyjna, wskład której wchodzą obecnie szkoła podstawowa, gimnazjum (wygaszane) oraz liceum ogólnokształcące. Choć z zewnątrz nic na to nie wskazuje, jest to miejsce niezwykłe i mogące poszczycić się bardzo bogatą historią, sięgającą początków XX wieku.

$\mathrm{W}$ artykule zostanie przedstawiony jeden z bardziej dramatycznych okresów w dziejach tego miejsca. Będzie nim czas Powstania Warszawskiego, który w klasztorze Sióstr Zmartwychwstanek zapisał się w sposób szczególny. Powrót do tych z trudem dających się opisać momentów, jest możliwy dzięki trzem lekturom, które stanowią najważniejsze pozycje w bibliografii niniejszego artykułu. Są nimi: Dziennik pielęgniarki z Powstania Warszawskiego autorstwa s. Emilii Radziszewskiej², książka Widziane ze schronu napisana przez s. Melanię Palm ${ }^{3}$ oraz opracowanie s. Marii Lucyny Misteckiej ${ }^{4}$

\footnotetext{
${ }^{1}$ Zgromadzenie Sióstr Zmartwychwstania Pana Naszego Jezusa Chrystusa, zwane też Zgromadzeniem Sióstr Zmartwychwstania Pańskiego (zmartwychwstanki), powstało w Rzymie w dniu 6 stycznia 1891 r. Zostało założone przez dwie Polki, Celinę Borzęcką i jej córkę Jadwigę. Powołaniem Zgromadzenia jest wielbienie Boga i głoszenie światu prawdy o Jego miłości przez uczestnictwo w Paschalnym Misterium Zbawienia. Siostry odwzajemniają tę miłość, idąc za Chrystusem, zgodnie z hasłem Zgromadzenia „przez krzyż i śmierć do zmartwychwstania i chwały”, a także dzieląc się dobrem wynikającym z otrzymanego charyzmatu. Łącząc życie kontemplacyjne z działalnością apostolską, starają się o religijne i moralne odrodzenie świata w duchu ewangelicznych błogosławieństw. Otwierają się na potrzeby bliźnich, posługując jako nauczycielki, wykładowczynie, wychowawczynie, przewodniczki duchowe, misjonarki, animatorki, rekolekcjonistki, katechetki, pielęgniarki, opiekunki dzieci, chorych, starszych i potrzebujących. Aktualnie siostry pełnią swoją misję w Polsce, we Włoszech, w Stanach Zjednoczonych, Kanadzie, Wielkiej Brytanii, Australii, Argentynie, na Białorusi, a także w Tanzanii. Całym swoim życiem - słowem, modlitwą i pracą apostolską - głoszą Dobrą Nowinę o Zmartwychwstaniu Chrystusa, realizując w ten sposób paschalny charyzmat Zgromadzenia. Por. M. L. Mistecka, Zmartwychwstanki charyzmat i dzieje 1891-1991, Lublin 2000, t. II, s. 313-530.

${ }^{2}$ S. Emilia - Maria Radziszewska, ur. 1 listopada 1908 r. w Łojewie. W szpitalu powstańczym pełniła funkcję pielęgniarki. Zmarła w Częstochowie dnia 23 września 2003 r. w wieku 95 lat (w Zgromadzeniu: 70 lat). Zob. M. L. Mistecka, Zgromadzenie Sióstr Zmartwychwstania Pańskiego w czasie Powstania Warszawskiego, Lublin 1980, s. 137.

${ }^{3}$ S. Melania - Melania Palm, ur. 29 kwietnia 1909 r. w Warszawie. W trakcie Powstania przebywała w żoliborskim klasztorze i opiekowała się dziewczętami, które pozostały na czas wakacji w szkolnym internacie. Zmarła w Mocarzewie dnia 6 lutego 2001 r. w wieku 91 lat (w Zgromadzeniu: 73 lata). Zob. M. L. Mistecka, Zgromadzenie Sióstr..., dz. cyt., s. 138.

${ }^{4}$ S. Maria Lucyna - Lucyna Mistecka, ur. 28 października 1930 r. w Natalinie na Wileńszczyźnie. W 1955 r. wstąpiła do Zgromadzenia Zmartwychwstanek. W 1957 r. złożyła pierwsze śluby. Ukończyła studia magisterskie i doktoranckie na Katolickim Uniwersytecie Lubelskim. W 1980 r. została wybrana radną generalną. W 2002 r. powróciła do prowincji macierzystej. Jest autorką wielu ważnych publikacji dotyczących historii Zgromadzenia: m.in. trzech tomów pt. Zmartwychwstanki charyzmat i dzieje 18911991, Zmartwychwstanki w okupowanej Polsce oraz Zmartwychwstanki w czasie Powstania Warszawskiego. Przygotowywała ponadto trzy tomy listów Matki Celiny do córki Jadwigi z lat 1893-1894. Zmarła w Częstochowie dnia 10 lutego 2005 r. w wieku 74 lat (w Zgromadzeniu: 50 lat). Zob. Nekrolog s. M. Lucyny Misteckiej autorstwa s. Teofili Matusiak, mps.
} 
pt. Zgromadzenie Sióstr Zmartwychwstania Pańskiego w czasie Powstania Warszawskiego, będące pierwszą próbą całościowego ukazania życia i posługi sióstr zmartwychwstanek w 1944 roku. Wymienione publikacje nie są dostępne dla szerszego grona odbiorców, co tym bardziej skłania do przywołania ich przesłania i treści.

Wobec podjętego zagadnienia pojawiają się pytania, jak warunki powstańcze wpłynęły na życie i posługę sióstr. Czy były one w stanie zachować styl życia właściwy osobom zakonnym? Czy w tak trudnych chwilach potrafiły nieść innym pomoc i dodawać otuchy potrzebującym pocieszenia? Jaki przykład dawały bliźnim? Czy bliska relacja z Bogiem i modlitwa pomogły im przeżyć tragiczne chwile? Na te i podobne pytania postaram się odpowiedzieć przywołując wspomnienia sióstr zawarte w wyszczególnionych powyżej lekturach. Temat ten zostanie przedstawiony na płaszczyźnie historycznej, ukazując funkcjonowanie zakonu jako szpitala powstańczego do momentu ewakuacji, jak i problemowej, ilustrując dezorganizację codziennego życia sióstr w obliczu Zagłady i ich heroiczne wysiłki podjęte celem sprawowania typowej posługi.

Przed przystąpieniem do analizy wybranego tematu warto napisać kilka słów o historii klasztoru Sióstr Zmartwychwstanek na warszawskim Żoliborzu. W 1928 r. Zgromadzenie rozpoczęło budowę olbrzymiego kompleksu zwanego „Zakładami Naukowo-Wychowawczymi Sióstr Zmartwychwstanek”, w którym mieściły się seminarium nauczycielskie, przedszkole, szkoła powszechna, gimnazjum oraz liceum ogólnokształcące. Na ich czele stanęła wówczas s. Amata Kossowska ${ }^{5}$. Pomimo trudnych wojennych warunków, do momentu wybuchu Powstania, każdego roku w czasie wojny w liceum na Żoliborzu odbywał się egzamin maturalny. Ponadto, regularnie organizowano akademie patriotyczne i religijne, rekolekcje i dni skupienia, warsztaty oraz spotkania absolwentek. Podczas okupacji tajnym nauczaniem zostało objętych ok. 1000 dzieci i młodzieży, a w bardzo dobrze wyposażonym internacie mieszkało ok. 100 dziewcząt. W klasztorze żyło zaś ponad 90 sióstr zmartwychwstanek. Posługa sióstr nie ograniczała się jednak tylko do działalności oświatowej, ale obejmowała również pracę charytatywną na rzecz najbardziej ubogich i potrzebujących. Jak pokazują powyższe dane, szczytowym momentem rozwoju żoliborskiej placówki był właśnie czas okupacji ${ }^{6}$.

\section{Klasztor jako szpital i twierdza powstańcza}

Po wybuchu Powstania Warszawskiego (1 sierpnia 1944 r.) szkoła i klasztor zamieniły się na szpital powstańczy, będący największym punktem sanitarnym na terenie XXII obwodu Armii Krajowej na Żoliborzu. Komendantem tego rejonu został ppłk Mieczysław Niedzielski, pseudonim „Żywiciel”. Miejsce to zostało objęte planem przygotowań do Powstania już

\footnotetext{
${ }^{5}$ S. Amata - Marta Kossowska, ur. 19 lipca 179 r. w Warszawie. W 1919 r. wstąpiła do Zgromadzenia Sióstr Zmartwychwstanek. Dwa lata później złożyła pierwsze śluby zakonne i rozpoczęła pracę nauczycielską. W 1930 r. stanęła na czele klasztoru i szkół żoliborskich. Zmarła w Warszawie w dnia 22 marca 1934 r. Zob. M. L. Mistecka, Zgromadzenie Sióstr..., dz. cyt., s. 20.

${ }^{6}$ Zob. M. L. Mistecka, Zgromadzenie Sióstr..., dz. cyt., s.20-22.
} 
w połowie 1942 r. Swoją gotowość wyraziły wtedy Matka Małgorzata Dąbrowska ${ }^{7}$, ówczesna przełożona prowincjalna, i s. Beata Przybyłowicz ${ }^{8}$, przełożona domu żoliborskiego.

W 1944 r. została zaprzysiężona lekarka - s. Amata Pruszko ${ }^{9}$. Od dnia 26 lipca do klasztoru przetransportowano kilka ton żywności dla potrzeb organizowanego szpitala (m.in. mąki, kaszy, grochu, suszonych ziemniaków, soli, cukru i konserw mięsnych). Dodatkowo, klasztor zaopatrzono w niezbędne wyposażenie lecznicze. Jak wyjaśnia s. M. L. Mistecka, działania te były bardzo niebezpieczne, ponieważ w przypadku rewizji posiadanie tak znacznych zapasów pożywienia, materiałów opatrunkowych, leków i narzędzi chirurgicznych trudno byłoby usprawiedliwić, nawet powołując się na istnienie schronu przeciwlotniczego w suterenach budynku ${ }^{10}$. Należy podkreślić, że pomimo tak szeroko zakrojonych przygotowań usytuowanie szpitala powstańczego nr 100 było do końca utrzymywane w tajemnicy do tego stopnia, że nawet siostry (z wyjątkiem kilku wtajemniczonych w to przedsięwzięcie) zostały poinformowane przez przełożoną o fakcie ulokowania szpitala w budynku zakonnym dopiero w dniu wybuchu Powstania.

Można zapytać, co zadecydowało o wyborze klasztoru na miejsce szpitala powstańczego. Przede wszystkim było to jego położenie w pobliżu centrum dzielnicy oraz łatwość ukrycia przygotowań do wybuchu Powstania pod pozorem prowadzonego przez siostry internatu. Ponadto, znaczenie miała spora liczba zakonnic, które można było zaangażować do pracy w charakterze personelu szpitala, oraz uczennic, które służyły w Powstaniu jako łączniczki i sanitariuszki.

\footnotetext{
${ }^{7}$ S. Małgorzata - Maria Izabela Dąbrowska, ur. 12 września 1880 r. w Michałowicach k. Krakowa. Do Zgromadzenia wstąpiła 28 września 1901 r. Pierwsze śluby złożyła 12 czerwca 1903 r. Podczas III Kapituły Generalnej została wybrana na urząd przełożonej generalnej. Posługę tę pełniła przez 12 lat w okresie od 1926-1938 roku. Następnie została przełożoną Prowincji Warszawskiej - jej urzędowanie przypadło na czas wybuchu Powstania Warszawskiego. Zmarła 10 października 1948 r. w Kętach w wieku 68 lat (w Zgromadzeniu: 47 lat). Zob. M. L. Mistecka, Zgromadzenie Sióstr..., dz. cyt., s. 23.

${ }^{8}$ S. Beata - Maria Przybyłowicz, ur. 28 stycznia 1899 r. w Płocku. W marcu 1920 r. przybyła do Kęt i tam rozpoczęła postulat. Dnia 2 lutego 1921 r. odbyły się obłóczyny. Rok później s. Beata złożyła pierwsze śluby i wyjechała do Domu Alumnatu w Warszawie. W Stolicy kontynuowała studia uniwersyteckie oraz rozpoczęła pracę w Seminarium Nauczycielskim jako nauczycielka polonistyki. Profesję wieczystą złożyła w Kętach 2 lutego 1927 r. Od lipca 1927 r. została mianowana przez matkę generalną przełożoną domu zakonnego na Sewerynowie w Warszawie oraz objęła urząd Mistrzyni Alumnatu. Od roku 1930 pracowała w klasztorze na Żoliborzu jako nauczycielka języka polskiego. W 1938 r., po Kapitule Generalnej, została mianowana przełożoną Domu Żoliborskiego i piastowała ten urząd także w trakcie Powstania Warszawskiego. W styczniu 1946 r. została mianowana Przełożoną Prowincji Poznańskiej. Zmarła po ciężkiej chorobie 3 listopada 1950 r. w Poznaniu w wieku 51 lat (w Zgromadzeniu: 30). Zob. Nekrologi Zmarłych Sióstr Zmartwychwstania Pana Naszego Jezusa Chrystusa od lipca do grudnia 1981-1956, t. II, mps.

${ }^{9}$ S. Amata - Wanda Pruszko, ur. 12 czerwca 1912 r. w Warszawie. Ukończyła Wydział Lekarski Uniwersytetu Warszawskiego. Do Zgromadzenia Sióstr Zmartwychwstanek wstąpiła w 1941 r. Organizowała szpital powstańczy i posługiwała w nim jako lekarka. Za te zasługi Dowództwo Armii Krajowej odznaczyło ją Krzyżem Powstania Warszawskiego i Armii Krajowej. Zmarła w Warszawie dnia 2 marca 1985 r. w wieku 72 lat (w Zgromadzeniu: 44 lata). Zob. M. L. Mistecka, Zmartwychwstanki charyzmat i dzieje..., t. II, dz. cyt., s. 101.

${ }^{10}$ Zob. M. L. Mistecka, Zgromadzenie Sióstr..., dz. cyt., s. 49.
} 
Jak rozpoczęło się Powstanie na Żoliborzu? Dnia 1 sierpnia około godziny 14.00, czyli wcześniej, niż oficjalnie zaplanowano, w pobliżu klasztoru rozległa się pierwsza strzelanina. Godzinę później do klasztoru przybył niemiecki patrol i zażądał rewizji budynku, podejrzewając, że to właśnie stamtąd padły strzały. S. Rafaela Gdaniec ${ }^{11}$ dyżurująca w tym czasie na furcie, wspaniale władająca językiem niemieckim, pertraktowała z dowódcą. Polecono wszystkim opuścić gmach. Wtedy Niemcy zagrozili wszystkim obecnym rozstrzelaniem, jeśli na terenie domu zostanie znaleziona broń. Przeszukano pomieszczenia oraz przybyły tego dnia do sióstr konwój z mąką, w którym ukryte było uzbrojenie przeznaczone dla powstańców. Na szczęście podczas rewizji nic nie znaleziono. Co więcej, żołnierz niemiecki przechodząc przez sale z rozstawionymi łóżkami nie domyślił się ich przeznaczenia. Jak opisuje tę scenę s. M. L. Mistecka: „nie przypuszczał, że rozpoczęło się powstanie, gdyż nie pozostawiłby bez obsady gmachu, którego zdobycie kosztowało później Niemców wiele ofiar w ludziach i wiele materiału artyleryjskiego" ${ }^{2}$. Te chwile ogromnego napięcia s. E. Radziszewska relacjonuje w ten sposób: „Odeszli. A my - odetchnęliśmy głęboko - wracaliśmy z krawędzi śmierci do życia. Wróciłyśmy do opustoszałego chwilowo domu - naszego domu - naszego klasztoru. Nie przypuszczałyśmy, że będziemy w nim przebywały jeszcze zaledwie kilkanaście dni, a potem już nigdy nie zobaczymy go takim, jakim był przez czternaście lat swojego istnienia. Pierwszy akt, a raczej wstęp do rozpoczynającej się »Rapsodii Warszawskiej i Żoliborskiej« w naszym domu został zakończony” ${ }^{13}$.

Działalność szpitala, usytuowanego początkowo w części parterowej klasztoru od ulicy Krasińskiego w nieistniejącej już części budynku, rozpoczęła się 1 sierpnia o godzinie 20.00. Tego dnia apostolstwo sióstr przybrało nową formę. Siostry posługiwały powstańcom jako lekarki, pielęgniarki, sanitariuszki, kucharki, a także pracując w pralni, szwalni, zapleczu gospodarczym i czuwając przy furcie. Jeszcze dwa dni wcześniej nikt nie przypuszczał, jakie dramatyczne sceny będą rozgrywać się na terenie klasztoru i jak głęboko wpłyną one na życie każdej siostry. Pod datą 30 lipca s. M. Palm zanotowała: „Była to niedziela. [...] Siostry wychodziły z kaplicy. [...] Nikt nie przypuszczał, że dni tragiczne są tuż za progiem. I nikomu z uczestników niedzielnego nabożeństwa nie przyszło na myśl, że w tej pięknej kaplicy nie zbierzemy się już nigdy więcej, ani następnej, ani żadnej niedzieli, że z niej wkrótce nie zostanie - dosłownie kamień na kamieniu" ${ }^{14}$.

\footnotetext{
${ }^{11}$ S. Rafaela - Joanna Gdaniec, ur. 26 marca 1900 r. w Bydgoszczy. W 1921 r. wstąpiła do Zgromadzenia Sióstr Zmartwychwstanek, a dwa lata później złożyła pierwsze śluby. Ukończyła seminarium nauczycielskie oraz konserwatorium muzyczne. Następnie pracowała jako nauczycielka śpiewu i języka niemieckiego. Ze względu na bardzo dobrą znajomość języka obcego w czasie okupacji była wyznaczona do załatwiania spaw urzędowych. W trakcie Powstania Warszawskiego zajmowała się w administracją szpitala. Po wojnie pełniła obowiązki radnej Prowincji Poznańskiej. Zmarła w Poznaniu 27 stycznia 1979 r. w wieku 79 lat (w Zgromadzeniu: 57 lat). Zob. M. L. Mistecka, Zmartwychwstanki charyzmat i dzieje..., t. II, dz. cyt., s. 288.

${ }^{12}$ M. L. Mistecka, Zgromadzenie Sióstr..., dz. cyt., s. 46.

${ }^{13}$ E. Radziszewska, Dziennik Pielęgniarki z Powstania Warszawskiego, Częstochowa 1996.

${ }^{14}$ M. Palm, Widziane ze schronu, Częstochowa 2001, s. 10.
} 
Pierwsze walki oszczędziły budynek klasztorny, ale szpital znalazł się w bardzo niepewnym położeniu, co uniemożliwiło punktualne stawienie się części obsady lekarskiej. Operacje i zabiegi trwały nieprzerwanie, a liczba rannych (żołnierzy i ludności cywilnej) nieustannie wzrastała. Bezpieczeństwo Zgromadzenia i rannych miała gwarantować Konwencja Genewska, zakładająca neutralność szpitali. Na dachu rozpostarto więc flagi z czerwonym krzyżem i nie wpuszczano nikogo z bronią. Budynek czasowo pozostał poza linią obrony, co umożliwiło staranną opiekę lekarską i utrzymanie należytej higieny: codzienne obchody lekarskie oraz właściwe przygotowywanie narzędzi chirurgicznych i materiałów opatrunkowych przez ich sterylizację chroniły pacjentów przed śmiertelnymi zakażeniami.

Niestety ten stan rzeczy nie trwał długo - już od 3 sierpnia szpital był systematycznie bombardowany przez samoloty wroga oraz ostrzeliwany przez pociąg pancerny z rejonu Dworca Gdańskiego. Skutkiem tego uszkodzeniu uległa część sali operacyjnej. Przeniesiono ją więc w inne skrzydło budynku, tym razem na parter i do suteren od ulicy Stołecznej. Praca załogi szpitala i sióstr stała się ekstremalnie trudna: 7 sierpnia nie było dostępu do sieci elektrycznej, dlatego operowano przy świetle gromnic i lamp. Pojawił się też problem braku wody. Na szczęście w ciągu kilku dni udało się czasowo przywrócić dostęp do tych niezbędnych mediów ${ }^{15}$.

Trudnym momentem był 10 sierpnia. Tego dnia ostrzeliwanie klasztoru rozpoczęło się już o 5.30 rano. W ciągu godziny na budynek padły 142 pociski, niszcząc część szpitalną. Szpital przeniesiono więc całkowicie do suteren. Warunki stawały się coraz cięższe. W ciągu dwóch tygodni trwania walk wyczerpały się dostarczone zapasy żywności, które na wszelkie sposoby starano się uzupełniać. Ewakuowano pobliskie szpitale i dostarczono siostrom nowych rannych, tak że 17 sierpnia przebywało tam ok. 200 pacjentów ${ }^{16}$. Siostra M. Palm relacjonuje: „Przed Najświętszym Sakramentem siostry leżały po kilka krzyżem, ustawicznie błagając Pana o miłosierdzie. Niezliczoną ilość razy w ciągu dnia schron-kaplica wypełniał się szczelnie. W chwilach bombardowania czułyśmy się tam najbezpieczniejsze. Siostry opiekujące się rannymi zostawały zawsze z nimi. Twierdziły, że wśród pracy zapominały o grozie sytuacji, a ta stawała się coraz wyraźniej sytuacją tonącego z wolna, ale nieuchronnie okrętu. Dom otrzymywał bowiem coraz to nowe uderzenia, które od III piętra do parteru wyrywały zeń ogromne kawały muru. Każde uderzenie pocisku odczuwało się jak bolesne zranienie żywego organizmu. Nie widziałyśmy z zewnątrz naszego klasztoru, ale sądząc po tym, co działo się nad naszymi głowami, wyobrażałyśmy sobie, że ściany jego muszą wyglądać jak sito. Stał jednak, nie walił się, mimo usiłowań Niemców, którzy traktowali go jak twierdzę, przeznaczoną na zrównanie z ziemią. Budowany był chyba na czas... powstania 1944 r. Grube mury solidnej roboty przedłużały teraz życie co najmniej dwustu osobom chroniącym się w suterenach" ${ }^{\prime 17}$.

\footnotetext{
${ }^{15}$ Zob. M. L. Mistecka, Zgromadzenie Sióstr..., dz. cyt., s. 52.

${ }^{16}$ Zob. M. Palm, Widziane ze schronu, dz. cyt., s. 53.

${ }^{17}$ Tamże, dz. cyt., s. 36-37.
} 
Należy podkreślić, że wśród pacjentów szpitala byli nie tylko żołnierze, ale także łączniczki, sanitariuszki oraz ludność cywilna. Do szpitala zaczęto przynosić również rannych Niemców, którzy nie zdołali wydostać się z pola walki. Początkowo zachowywali się nieufnie, nie chcieli jeść i pić, spodziewając się otrucia. Jednak obserwując szlachetną postawę personelu szpitala, przełamywali swój upór. Byli zdziwieni, że otrzymują takie same racje żywnościowe jak Polacy, a nawet trudno dostępne papierosy. Jak zauważyła w swojej książce s. M. L Mistecka: „tak byli traktowani jeńcy w Szpitalu Zmartwychwstanek, podczas gdy wróg w tym samym czasie palił żywcem polskich lekarzy, pielęgniarki i nawet chorych w szpitalu na Woli”" ${ }^{18}$.

Obok klasztoru nieustannie toczyły się walki, wskutek których w budynek trafiały kolejne kule, tym razem 27 pocisków artyleryjskich. Niemcom udało się również podpalić część budynku, ale pożar szczęśliwie ugaszono z pomocą ofiarnych sąsiadów. Jak zaznacza s. M. L. Mistecka, nie był to jedyny przypadek, w którym okoliczni mieszkańcy przybyli na ratunek. Wspierali oni działalność szpitala od momentu, kiedy tylko dowiedzieli się o jego istnieniu. Ofiarnie dzielili się własnymi dobrami, dostarczając to, czego w danej chwili brakowało. Z narażeniem życia przynosili do klasztoru żywność, pościel, bieliznę, czasem również mięso, wino, słodycze i papierosy, a także kwiaty do ozdobienia kaplicy. Niestety potrzeby szpitala nie mogły być w pełni zaspokajane przez ludność cywilną, której majątek wskutek działań zbrojnych z dnia na dzień ulegał uszczupleniu ${ }^{19}$.

\section{Nowe warunki życia i formy postugi sióstr}

Bez wątpienia dzień 1 sierpnia rozpoczął nowy rozdział życia i posługi żoliborskich zmartwychwstanek. Wszystko zostało podporządkowane rzeczywistości wojennej. Mimo granicznego zmęczenia siostry wstawały codziennie rano na modlitwę, rozmyślanie i Eucharystię. Dzięki zaradności zakrystianki, s. Antonetty Tomaszewicz ${ }^{20}$, która wcześniej zaopatrzyła kaplicę w tysiące komunikantów, codziennie sprawowano msze święte. W klasztorze przebywało w tym czasie trzech księży ${ }^{21}$. Po rozpoczęciu walk nie mogli już wydostać się z oblężonej dzielnicy. Kapłani posługiwali na różne sposoby: sprawowali Najświętszą Ofiarę, spowiadali, ale także opiekowali się rannymi.

Po porannej toalecie, mszy św. i skromnym śniadaniu siostry odchodziły do swoich obowiązków. Najbardziej wymagającymi z nich była praca w kuchni i pralni. Do momentu ewakuacji szpitala posiłki dla chorych były dość dobre, co było możliwe dzięki żywności dostarczonej przed wybuchem powstania, jak również dzięki zapasom będącym własnością Zgromadzenia oraz darom ludzi dobrej woli. Zgodnie z zaleceniem

\footnotetext{
${ }^{18}$ M. L. Mistecka, Zgromadzenie Sióstr..., dz. cyt., s. 56.

${ }^{19}$ Tamże, s. 60-61.

${ }^{20}$ S. Antonetta - Helena Tomaszewicz, ur. 9 sierpnia 1909 r. w Bukatach (woj. wileńskie). W czasie Powstania pełniła obowiązki zakrystianki żoliborskiego klasztoru. Zmarła w Mocarzewie 10 grudnia 1996 r. w wieku 87 lat (w Zgromadzeniu: 67 lat). Zob. M. L. Mistecka, Zgromadzenie Sióstr..., dz. cyt., s. 136.

${ }^{21}$ Kapłanami tymi byli: ks. Eugeniusz Żelazowski, kapelan żoliborskiego klasztoru, spowiednik sióstr ks. J. Cecholm oraz ks. A. Grzymała. Zob. M. L. Mistecka, Zgromadzenie Sióstr..., dz. cyt., s. 46. Nie umiem znaleźć pozostałych imion kapłanów. Musimy zapytać autorkę, albo zrezygnować z imion...
} 


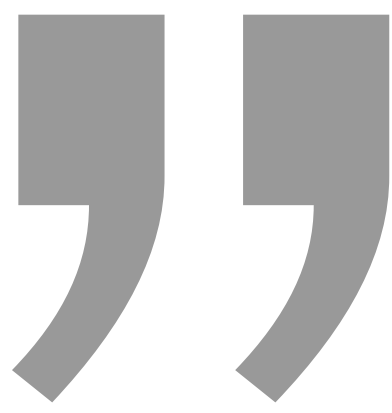

Siostry były zmuszone oswajać się z coraz bardziej spartańskimi warunkami egzzystencji. Po 10 sierpnia musiały przenieść się do suteren, co znacznie zmniejszyło ich przestrzeń życiową Nie było mowy o swobodnym poruszaniu się, a zajęcie wygodnej pozycji graniczyło z cudem. Brakowało osobnego miejsca na spoczynek, dlatego siostry spały gdziekolwiek: na podłodze, krzesłach, a nawet klęcznikach znajdujących się w prowizorycznie urządzonej kaplicy.

s. Przełożonej B. Przybyłowicz, posiłki otrzymywali także członkowie rodzin personelu szpitala, pracującego bez wytchnienia dnie i noce. Niestety w miarę upływu czasu wyżywienie wszystkich stawało się niemożliwe ze względu na brak artykułów spożywczych i wyposażenia kuchennego. Coraz trudniej było także utrzymać właściwą higienę. Brak wody i mydła, a później także przestrzeni odpowiedniej na zorganizowanie suszarni uniemożliwiały normalne funkcjonowanie pralni ${ }^{22}$.

Siostry były zmuszone oswajać się z coraz bardziej spartańskimi warunkami egzystencji. Po 10 sierpnia musiały przenieść się do suteren, co znacznie zmniejszyło ich przestrzeń życiową. Nie było mowy o swobodnym poruszaniu się, a zajęcie wygodnej pozycji graniczyło z cudem. Brakowało osobnego miejsca na spoczynek, dlatego siostry spały gdziekolwiek: na podłodze, krzesłach, a nawet klęcznikach znajdujących się w prowizorycznie urządzonej kaplicy. Nad ich głowami przenoszono zwłoki zmarłych i pod osłoną nocy zakopywano je bez trumien w dole od ul. Stołecznej ${ }^{23}$.

Siostra. M. Palm najbardziej dramatycznie wspomina pierwsze dziewięć dni Powstania, kiedy to wszyscy byli zmuszeni oswoić się z niebezpieczną rzeczywistością. Jej wspomnienia dobrze ukazują nie tylko grozę sytuacji, ale przede wszystkim godną podziwu postawę zakonnic, które w tak tragicznych momentach nie traciły wiary, lecz trwały na modlitwie i były gotowe oddać życie za innych. W książce Widziane ze schronu zapisuje: „W tłoku, w mrocznym korytarzu suteren stałyśmy jedna przy drugiej z różańcami w rękach i modliłyśmy się, odczuwając każdym drgnieniem duszy drżenie gmachu od rozrywających się pocisków i bolesny skurcz serca, gdy celnie wymierzony strzał [...] zadawał domowi nową ranę. A przecież to było jeszcze niczym wobec świado-

\footnotetext{
${ }^{22}$ Zob. M. L. Mistecka, Zgromadzenie Sióstr..., dz. cyt., s. 59, 62.

${ }^{23}$ Tamże, dz. cyt., s. 63-64.
} 
mości, że ginie w pobliżu Warszawa [...] a wśród niej siostry na Mokotowskiej, Chłodnej, nasza najdroższa Matka Prowincjalna Małgorzata Dąbrowska. Żadna wieść nie docierała na Żoliborz, który był zupełnie odcięty od miasta, podobny do wysepki otoczonej Niemcami. Tak minęło dziewięć dni. Najdłuższa i najcięższa nowenna cierpienia. Gdyby nie wymowa dat i wtedy, i dziś - trudno byłoby uwierzyć, że to tylko dziewięć dni... Okres ten wydaje się niepomiernie dłuższym, najdłuższym z całego powstania. Może dlatego, że dopiero wdrażałyśmy się do nowych, nad wyraz prymitywnych warunków bytowania, oswajałyśmy się ze wzrastającą grozą sytuacji, traciłyśmy drogi nasz dom, w którym niejedna spędziła znaczną część swojego życia. Bóg odrywał nas od wszystkiego, co doczesne, byłyśmy w pełnym ufności zdaniu się na Jego wolę, przygotowywałyśmy się do ostatniego momentu, do chwili opuszczenia tego srogiego czyśćca i spotkania się z Nim na wieki”²4.

Rzeczywistość wojenna zdezorganizowała życie zakonne we wszystkich jego aspektach. Działania wojenne uniemożliwiły należyte przeprowadzenie uroczystości profesji zakonnej s. M. Pauli Dąbrowskiej ${ }^{25}$. Dnia 11 sierpnia s. Paula złożyła na ręce siostry przełożonej śluby wieczyste, przyspieszone w obawie o życie zakonnic, które ze względu na narastające zagrożenie mogły nie dożyć 15 sierpnia. Wtedy to przypada właściwy dzień składania ślubów w Zgromadzeniu. Relacja s. E. Radziszewskiej dotycząca tego szczególnego momentu jest bardzo lakoniczna: „Zamknięte w naszym domu, jak w skazanym na zagładę okręcie, przeżyłyśmy... uroczystość zakonną... Rankiem, podczas cichej Mszy św. przy akompaniamencie dział nasza Siostra poświęciła się Chrystusowi na zawsze. Jedyna to chyba w dziejach Zgromadzenia profesja zakonna w takich warunkach"26.

\section{Ewakuacja szpitala i zagłada „Iwierdzy Zmartwychwstanek”}

W miarę upływu czasu Klasztor Zmartwychwstanek stał się ostatnim budynkiem zamykającym Niemcom dostęp do Placu Wilsona od strony Cmentarza Powązkowskiego. W ocenie dowództwa nie był już bezpiecznym miejscem dla ludności cywilnej, dlatego siostry oraz wszyscy jego tymczasowi mieszkańcy otrzymali nakaz opuszczenia gmachu. Z uwagi na grożące niebezpieczeństwo, z dnia 18 na 19 sierpnia zarządzono ewakuację szpitala. Ta niezwykle trudna i żmudna akcja trwała dwie noce. Siostry były zmuszone się rozdzielić. Te stanowiące personel szpitalny (w liczbie dwudziestu sześciu osób) poszły z chorymi i dzieliły ich los do końca. Sześć z nich zginęło podczas bombardowania dnia 31 sierpnia, bez wytchnienia służąc bliźniemu pomimo grożącego niebezpieczeństwa.

\footnotetext{
${ }^{24}$ M. Palm, dz. cyt., s. 41.

${ }^{25}$ S. Maria Paula - Józefa Dąbrowska, ur. 14 marca 1901 r. w Warszawie. Ukończyła studia ze specjalnością matematyki i fizyki. W 1936 r. wstąpiła do Zgromadzenia Sióstr Zmartwychwstanek. Dwa lata później, po ślubach, rozpoczęła pracę nauczycielską w szkole żoliborskiej. Tam też zastał ją wybuch powstania. Zmarła w Częstochowie dnia 14 maja 1990 r. w wieku lat 89 (w Zgromadzeniu 63 lata). Zob. M. L. Mistecka, Zmartwychwstanki charyzmat i dzieje 1891-1991, t. III, Lublin 2002, s. 178-179.

${ }^{26}$ E. Radziszewska, Dziennik Pielęgniarki z Powstania Warszawskiego, dz. cyt., s. 153-154.
} 
Po opuszczeniu klasztoru służbę objęła tam 1. kompania im. Walerego Wróblewskiego. Jednostka ta dysponowała niewielką liczbą broni, na którą składały się 2 karabiny maszynowe, 14 karabinów, 19 pistoletów maszynowych, 26 pistoletów, 1 granatnik przeciwpancerny, 140 granatów ręcznych i 47 butelek zapalających ${ }^{27}$. Wobec niewielkiej ilości uzbrojenia konieczne stało się umocnienie budynku na wszelkie możliwe sposoby. Do tego celu używano nawet wyposażenia domowego, co było kolejnym uszczerbkiem na majątku zgromadzenia. Przy klasztorze wzniesiono barykady powstańcze, tworząc najważniejszą linię obrony Żoliborza. Był to nieugięty punkt obronny tej części miasta, stąd dwie nazwy „Reduta Żoliborza” i „Twierdza Zmartwychwstanek”. Określenia te miały także związek z faktem, że klasztor z uwagi na rozmieszczenie stanowisk niemieckiej artylerii uchodził za bezpieczne miejsce: do 25 września pociski wroga trafiały najczęściej w górne kondygnacje budynku. Klasztor pełnił dodatkowo dwie istotne funkcje defensywne. Jako najwyższy budynek na tym terenie wydawał się dobrym miejscem do prowadzenia stałej obserwacji. Od 20 września był jednym z punktów do kierowania ogniem artylerii radzieckiej i polskiej ostrzeliwującej niemieckie pozycje z rejonu Pragi. Ponadto, przed przeniesieniem szpitala przebywającym tam rannym żołnierzom otuchy dodawała pełna wiary i ufności postawa sióstr.

Przez cały czas trwania Powstania budynek klasztorny był regularnie ostrzeliwany - do połowy września codziennie sprawdzano otwory po pociskach, których naliczono czterysta. Śmiertelnym zagrożeniem spowodowanym uderzeniami pocisków artyleryjskich były pożary. Zaledwie przez dwa dni (27-28 sierpnia) ugaszono 58 ognisk.

Przygniatająca przewaga niemieckiej broni ciężkiej i brak skutecznej broni do zwalczania czołgów i dział szturmowych uniemożliwiły dłuższe utrzymanie pozycji bojowych. Dnia 29 września nastąpiło opuszczenie „Twierdzy Zmartwychwstanek”. Wcześniej odbył się apel, w którym uczestniczyło 53 żołnierzy, w tym 18 lekko rannych, oraz 6 sanitariuszek - razem 59 osób ze 117 obrońców budynku. W obronie klasztoru poległo 21 żołnierzy i sanitariuszek, 3 żołnierzy ciężko rannych zmarło, 20 dostało się do niewoli. Za odwagę w odpieraniu ataków niemieckiego okupanta ppłk M. Niedzielski, pseudonim „Żywiciel”, odznaczył dwóch żołnierzy krzyżami Virtuti Militari, a szesnastu Krzyżami Walecznych. Był to najbardziej wyróżniony orderami oddział powstańczy tej części miasta ${ }^{28}$.

W tym miejscu warto podkreślić, że „Twierdza Zmartwychwstanek” była jedyną pozycją powstańczego Żoliborza niezdobytą przez Niemców, lecz opuszczoną na rozkaz, z uwagi na bezcelowość dalszej obrony. Co więcej, wojska niemieckie nie zajęły klasztoru nawet po zakończeniu Powstania, obawiając się, że budynek został dokładnie zaminowany, jak umyślnie przekonywali wzięci do niewoli powstańcy.

Nie sposób pominąc informacji o ogromnych stratach, jakie Zgromadzenie Sióstr Zmartwychwstanek poniosło w trakcie działań zbrojnych. Wymienić trzeba chociażby 10 zabitych sióstr, uszczerbek na zdrowiu kilkunastu innych oraz zrujnowany w 70\% ma-

${ }^{27}$ Zob. M. L. Mistecka, Zgromadzenie Sióstr..., dz. cyt., s. 69.

${ }^{28}$ Tamże, dz. cyt., s. 89. 
jątek Zgromadzenia. Żoliborski gmach, choć po wojnie częściowo odbudowany, dzisiaj stanowi jedynie $1 / 3$ tego, co stało tu przed wojną.

Mimo niesprzyjających okoliczności oraz konieczności poniesienia olbrzymiego nakładu pracy i środków finansowych siostry nie poddały się, dlatego już na początku 1946 r. uczennice mogły wrócić do budynku na Krasińskiego, gdzie otworzono przedszkole, szkołę powszechną i pierwsze klasy gimnazjum. Już w kilka lat po wojnie szkoła dysponowała bogatym, jak na owe czasy, wyposażeniem w sprzęt dydaktyczny. Podziwem napełnia fakt, że siostry nie zrezygnowały z rozpoczętego wcześniej dzieła, ale zmobilizowały wszystkie siły, aby służyć dzieciom i młodzieży przez dalsze prowadzenie działalności oświatowej i wychowawczej.

W marcu 1958 r. podczas porządkowania ruin klasztoru wydobyto szkielety czterech poległych powstańców w wieku od 15 do 19 lat $^{29} .1$ kwietnia odprawiono mszę pogrzebową, po czym ekshumowane zwłoki złożono na Powązkowskim Cmentarzu Wojskowym. 6 maja w Liceum Zmartwychwstanek odbyła się uroczystość, uświetniona akademią z pieśniami powstańczymi, w czasie której przekazano Zgromadzeniu fragment sztandaru powstańczego, zdjętego z klasztoru w czasie ostrzału artylerii 29 września roku $1944^{30}$. Było to przypomnieniem dramatycznych dni Powstania Warszawskiego i odwagi tych, którzy mimo młodego wieku zdecydowali się oddać życie za wolność Ojczyzny. W tym miejscu można przywołać słowa s. Emilii Radziszewskiej, która wspominając swoją pielęgniarską posługę, zapisała: „Jeżeli powstanie w bezpośrednim swoim objawie było wybuchem miłości Ojczyzny i czynu dla niej, to szpital był przybytkiem jakiejś mistycznej atmosfery cierpienia, ofiary oraz cichej, a dumnej radości, że cierpi się za słuszną sprawę, za Polskę"31.

\section{Zakończenie}

Należy jeszcze raz podkreślić szczególny udział sióstr zmartwychwstanek w Powstaniu Warszawskim. Choć początkowo ich zadanie sprowadzało się do przygotowania łóżek i pomieszczeń dla rannych, z biegiem czasu objęło coraz to nowe obowiązki, podyktowane dramatycznym splotem wydarzeń i ogromnymi potrzebami bliźnich. Jakkolwiek wcześniej były one częściowo odizolowane od świata, w chwili wojny umiały dostosować się do trudnej sytuacji i współpracować z każdym dla dobra wszystkich.

Jak wykazała analiza dostępnych źródeł, siostry nie uchylały się od służby, ale z narażeniem własnego życia i spychając na drugi plan swoje własne potrzeby, ofiarnie posługiwały innym jako lekarki, pielęgniarki i pracownice zaplecza gospodarczego. Te wchodzące w skład personelu szpitala powstańczego do końca dzieliły swój los z tymi, którzy zostali powierzeni ich opiece. W chwilach grozy nie zapominały o klasztornym powołaniu, ale pozo-

\footnotetext{
${ }^{29}$ Jak podaje s. M. L. Mistecka, na podstawie dokumentów znalezionych przy ciałach zidentyfikowano następujące osoby: strzelca Gustawa Pawłowskiego (lat 15), żołnierza Bolesława Pilskiego ps. Pelikan (lat 16), sanitariuszkę Alicję Masłowską ps. Inka (lat 19). Zob. M. L. Mistecka, Zgromadzenie Sióstr..., dz. cyt., s. 125.

${ }^{30}$ Zob. M. L. Mistecka, Zgromadzenie Sióstr..., dz. cyt., s. 129.

${ }^{31}$ E. Radziszewska, Dziennik Pielęgniarki z Powstania Warszawskiego, dz. cyt., s. 87.
} 
stały wierne zobowiązaniom życia zakonnego. Dzięki temu mogły być dla innych duchowymi przewodniczkami na drodze zbawienia przez cierpienie, odważnie podążając - zgodnie z mottem Zgromadzenia - „przez krzyż i śmierć do zmartwychwstania i chwały”. Postawą ufnej modlitwy dodawały rodakom otuchy i były dla nich zwiastunkami pokoju i nadziei. Bez wątpienia miały nieoceniony wkład w budowę „Powstańczej Reduty Żoliborza” „Twierdzy Zmartwychwstanek”, która dla pokoleń Polek i Polaków jest symbolem heroicznej walki i bohaterstwa okupionego ceną życia.

\section{BIBLIOGRAFIA:}

Mistecka M. L., Zmartwychwstanki charyzmat i dzieje 1891-1991, t. II, Lublin 2000.

Mistecka M. L., Zmartwychwstanki charyzmat I dzieje 1891-1991, t. III, Lublin 2002.

Mistecka M. L., Zgromadzenie Sióstr Zmartwychwstania Pańskiego w czasie Powstania Warszawskiego, Lublin 1980.

Nekrologi Zmarłych Sióstr Zmartwychwstania Pana Naszego Jezusa Chrystusa od lipca do grudnia 1981-1956, t. II, mps.

Nekrolog s. M. Lucyny Misteckiej autorstwa s. Teofili Matusiak, mps.

Palm M., Widziane ze schronu, Częstochowa 2001.

Radziszewska E., Dziennik pielęgniarki z Powstania Warszawskiego, Częstochowa 1996.

\section{OAUTORCE:}

mgr lic. Joanna Pyszna - absolwentka Edukacji Medialnej i Dziennikarstwa oraz Teologii Duchowości Uniwersytetu Kardynała Stefana Wyszyńskiego w Warszawie. Zainteresowania badawcze: duchowość zakonna (w szczególności duchowość zmartwychwstańska) oraz teologia feministyczna.

Kontakt:joanna.pcp@gmail.com 